\title{
Numerical Modelling of the Slope: A Case Study of Dounia Park (North Algeria)
}

\author{
Taleb Hosni Abderrahmane ${ }^{1,2,{ }^{*}}$, Cheriet Fayssal ${ }^{3,4}$, Allout Naas ${ }^{3,5}$, Abdellaoui Merouane ${ }^{3}$ \\ ${ }^{1}$ Civil Engineering Department, Institute of Science and Technology, University Center of Abdelhafid Boussouf, Mila, Algeria \\ ${ }^{2}$ Reliability of Materials and Structures in the Saharan regions (FIMAS) Laboratory, University TAHRI Mohamed Bechar, Bechar, Algeria \\ ${ }^{3}$ Civil Engineering Department, Ziane Achour University, Djelfa, Algeria \\ ${ }^{4}$ Laboratory of Environment, Water, Geomechanics and Structures, Faculty of Civil Engineering, University Science and Technology Houari \\ Boumadienne, Algiers, Algeria \\ ${ }^{5}$ Civil Engineering Research Laboratory, University of Biskra, Biskra, Algeria
}

Email address:

talebhosni@yahoo.fr (T. H. Abderrahmane), cheriet.fayssal@yahoo.fr (C. Fayssal)

${ }^{*}$ Corresponding author

\section{To cite this article:}

Taleb Hosni Abderrahmane, Cheriet Fayssal, Allout Naas, Abdellaoui Merouane. Numerical Modelling of the Slope: A Case Study of Dounia Park (North Algeria). Mathematical Modelling and Applications. Vol. 6, No. 3, 2021, pp. 70-80. doi: 10.11648/j.mma.20210603.12

Received: December 19, 2020; Accepted: January 7, 2021; Published: October 12, 2021

\begin{abstract}
In this study, we describe the landslide of Dounia Park, Northen the capital Algiers, exactly in the city of Dely Ibrahim, near the Mercedes house. It is regarded as a huge park with games, and the green lungs of Algiers. This study is based on the configuration of the slope, mechanical properties and soil class, geology intervenes in the relief geomorphology and stratification, water, and earthquake shaking, etc..., the field observation has revealed the existence of land instabilities, cracks, and types of landslides (translation, rotation), in order to examine the landslides of Dounia Park, numerical modeling by the finite element limit analysis is employed to investigate this slope. The results obtained in this article show numerous points. During the site visit, it was observed that the area of Dounia Park is affected by many types of instabilities. Also, this paper show adequately give out the morphology of the slope instability observed on the site.
\end{abstract}

Keywords: Dounia Park, Slope Stability, Analysis, Finite Element Method

\section{Introduction}

The instability of slopes is one of the most damaging natural hazards in northern Algeria [1-7]. The landslides generally impose bad consequences in populated regions; they are the reason to extravagant life losses [8-9]. Statistically, the costs of landslides are between 1-5 billion US Dollars per year for each of the following countries, [9] USA, India, Japan, and Italy. Additionally, in Canada, the cost is about 70 million USD [10]. The formation of slides is due to many reasons. Firstly, the population growth is a main reason which calls for the creation of new cities and towns. The human activities can change the morphology or shape of slope, for example, by weakening the toe, incorrect excavating, causing fissures in the course of excavation, or deforestation, Other contribution are attached to surcharge loading: some of these loads may be short term, such as passage of vehicles, vibrations of machines; or they may be permanent, such as building construction. The landslides may also happen due to other human activities connected to water, such as leaking pipes, creating or draining of reservoirs, disturbing or varying drainage patterns. The second causes is related to nature, including: the configuration of the slope, mechanical properties and soil class, geology intervenes in the relief geomorphology and stratification, water, and earthquake shaking, etc... [11]. Many landslides have occurred during earthquakes. Northern Algeria is particularly menaced by many catastrophes due to the characteristic regional geological, geomorphological details, climate condition, mechanical properties and seismotectonic conditions, as well as anthropogenic aspects [12]. In this study we aims to analyze 
and assess the landslide of Dounia Park in North of Algeria. In this paper, the finite element method is used to analyses the area "Dounia Park".

\section{Landslides and Algeria's Location}

Algeria is situated in North Africa on the Mediterranean coast. The capital of Algeria it is Algiers, located in the country's far north, see figure 1. Algeria is the biggest country in Africa, with a space of 2,381,741 $\mathrm{Km}^{2}$ (square kilometers), and one of the largest countries in the world. Algeria shares land borders with 7 countries, the Mediterranean Sea to the north, Morocco and Western Saharan territory to the northwest, Mauritania, and Mali toward the southwest, Tunisia to the northeast, Libya to the east, Niger toward the southeast, see figure 2. As mentioned previously, there are various causal factors that make slopes instable. In the Algeiran context, the earthquake $(\mathrm{Mw}=5.7)$ in Mascara (northwest Algeria) in August 18th, 1994 lead rocks to block the roads [13]. In November 10th, 2000 many landslides were trigged due to earthquake in northeast Algeria Beni Ourtilane [14]. In the east of Algeria, on 20th of May (2003), northcenter Algeria (Boumerdes), seismic activity with power of $(\mathrm{Mw}=6.8)$ Have lead to numerous landslides throughout the area [15]. Climate change contributes to the instability or reactivation of landslides. Regarding Tizi-Ouzou, a region located in northern Algeria, many villages and towns witness activity of landslides for instance: Ain El Hammam, Azazga, Azzefoun, Tigzirt, and Tala Allam. [16]. Many landslides are triggered by rainfall, due to the human activities and may also occur by the unfavorable, hydrogeological, geotechnical and geological conditions. The first landslide is situated Southwest of Algiers, around to $250 \mathrm{~km}$ in Tissemsilt region, precisely in Bordj Bounaama. The second slope instability is one of the most marked among the 120 locations pretentious by landslides since 2000 in Béjaia, it is located in northeast region [17].

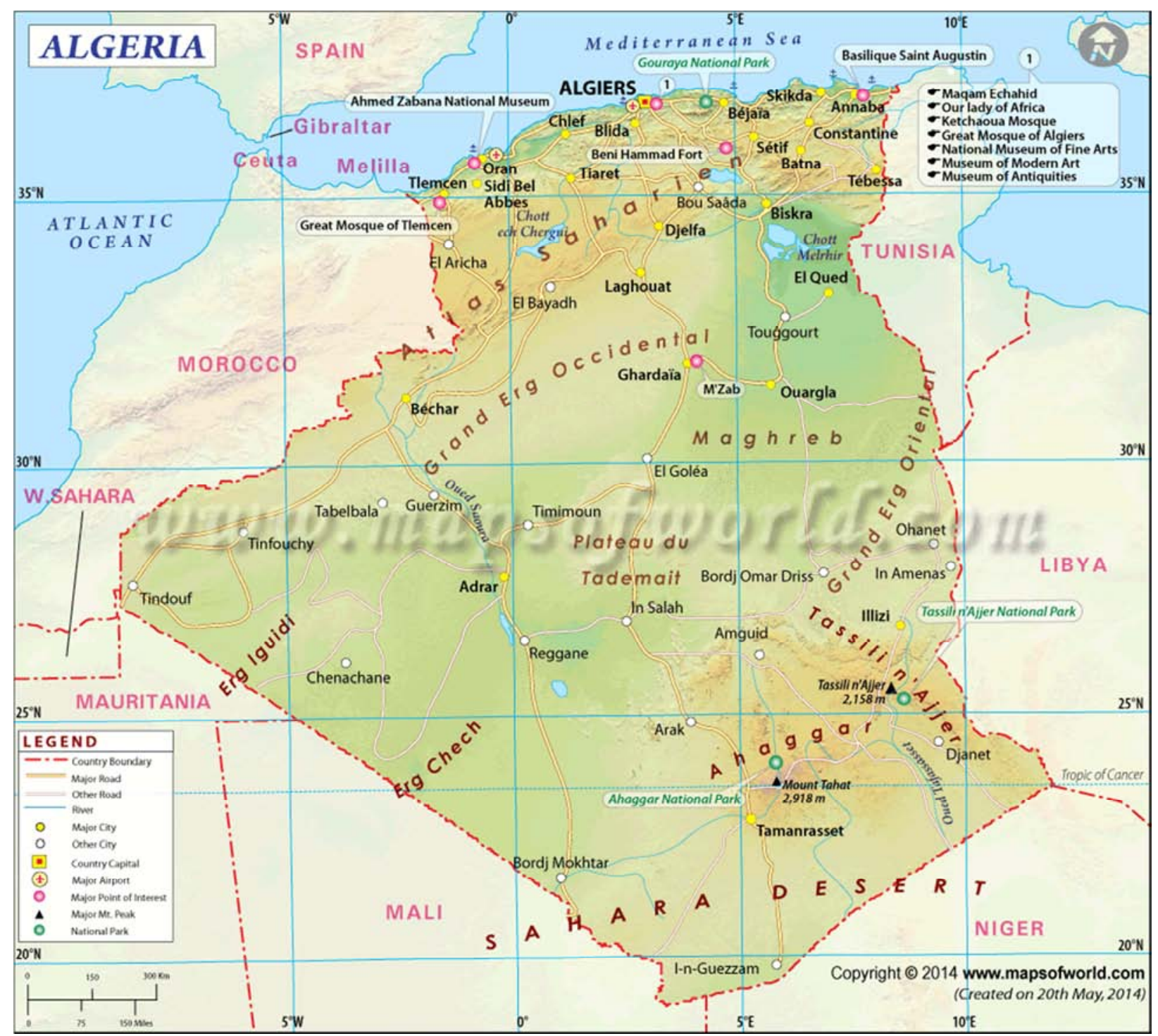

Figure 1. Map of Algeria (mapsofworld.com). 


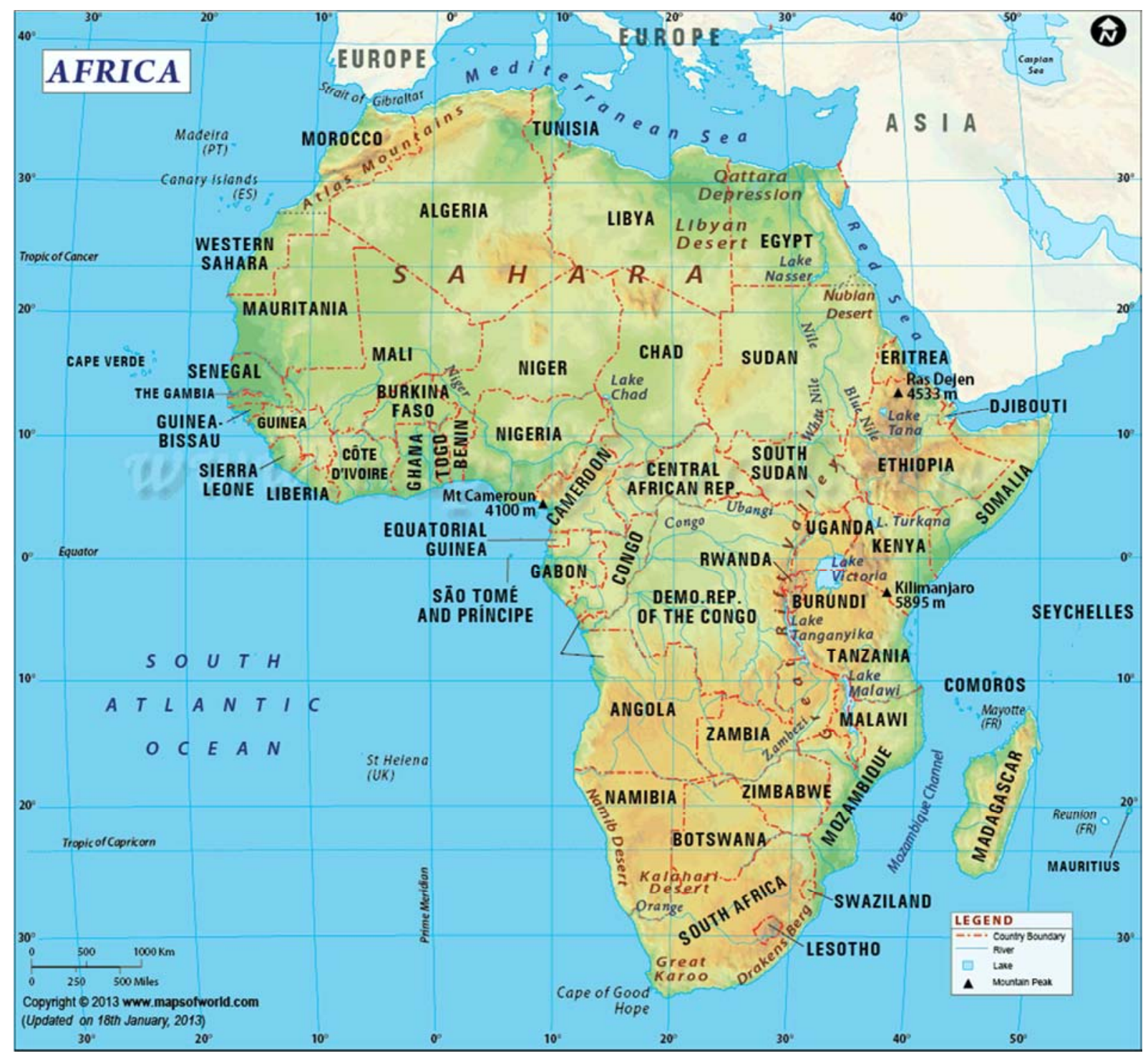

Figure 2. The position of Algeria in Africa map (mapsofworld.com).

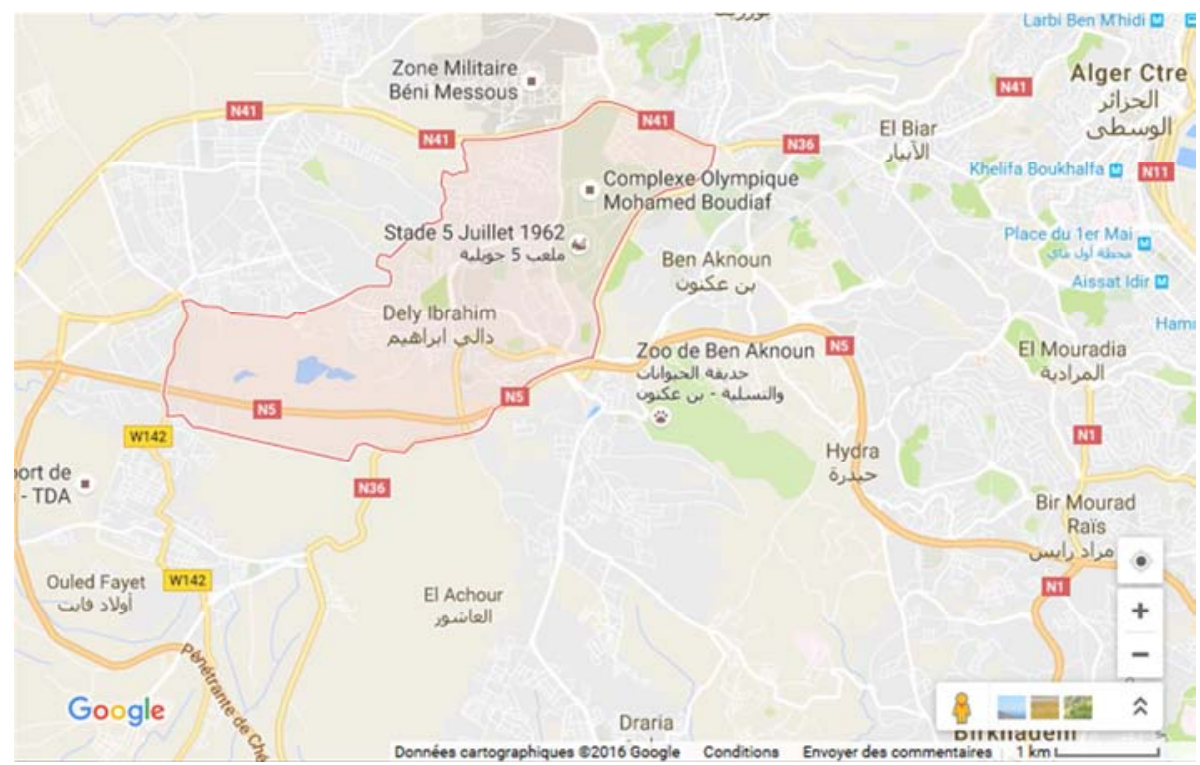

Figure 3. Dely Ibrahim location (Google map). 


\section{Presentation of the Study Zone (Dounia Park)}

Dounia Park is located in North of the capital (Algiers) exactly in Dely Ibrahim, see figure 3 (red color), near the Mercedes house. It is regarded as a huge park with games, and the green lungs of Algiers. Dely Ibrahim is bordered to the north by Beni Messous, to the northeast by Bouzareah, to the east by Ben Aknoun, to the west by Cheraga, to the south by Oueld Fayat and El Achour, see figure 4. The Park, with a total area of 65 hectares, is bordered by Highway of national road No. 01, in the north, Wilaya road in the south, So far there are habitations, to the East, and the Rest of the field (wasteland) to the west (figure 5).

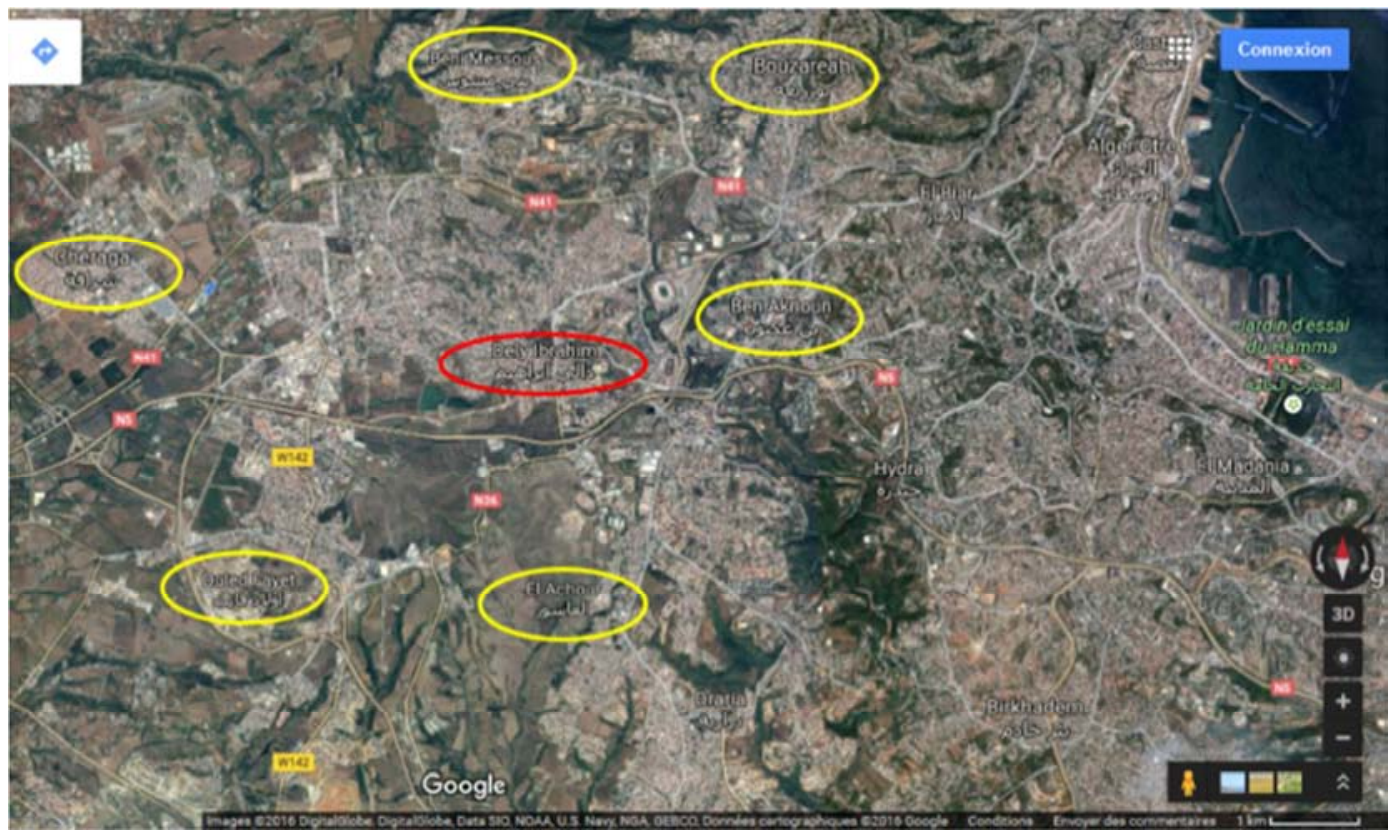

Figure 4. Google map view of Dely Ibrahim location, and its borders (Google map).

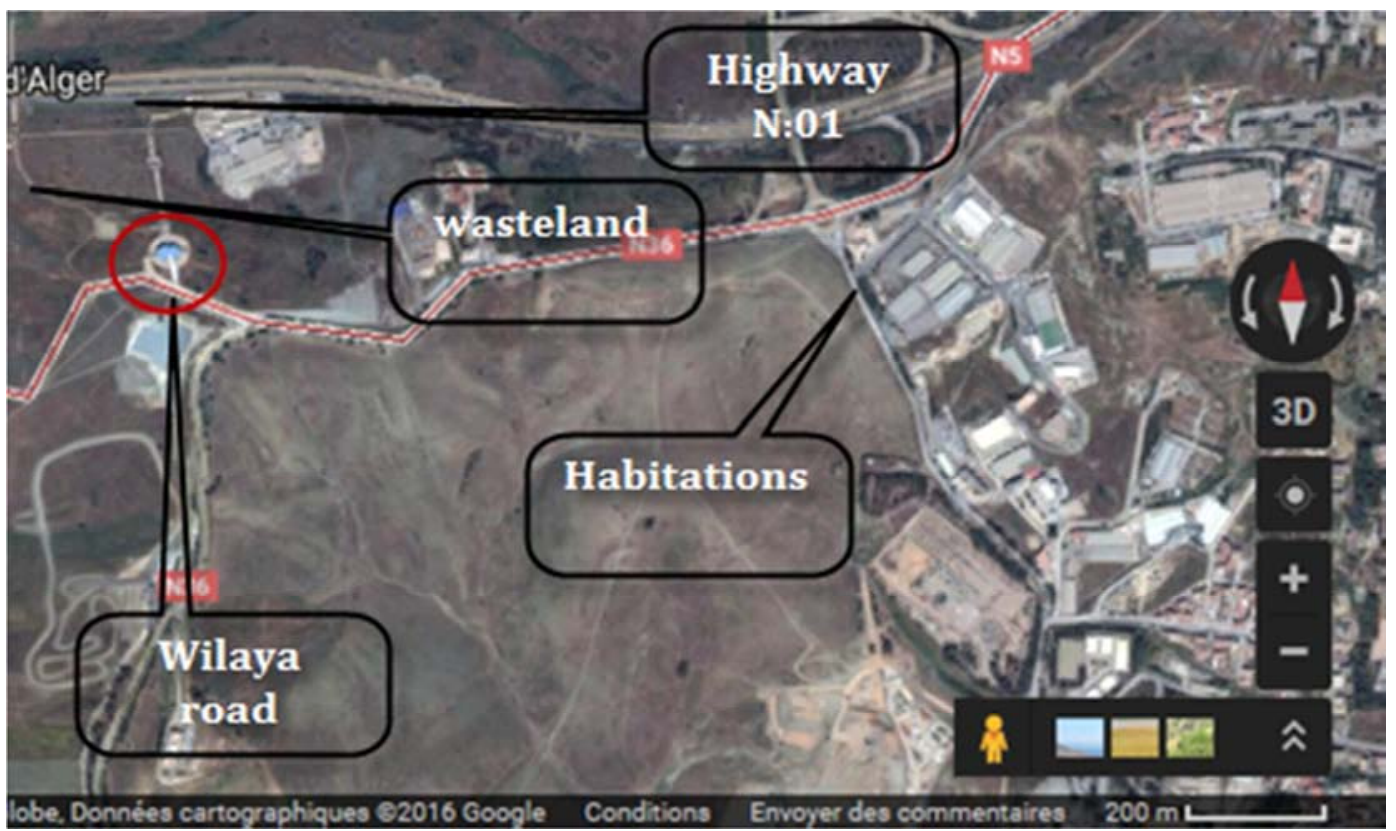

Figure 5. The position of Dounia Park, and its borders.

\subsection{Geological Survey}

The geology of this area taken from the card Cheraga (at $1 / 50,000)$ [18], highlighted the geological formations of the area, (figure 6). This region is sensitive to water, because it consists largely of marl. According to its degree of alteration, the plaisancian marl has different behaviors towards slope stability and its resistance to breaking. 


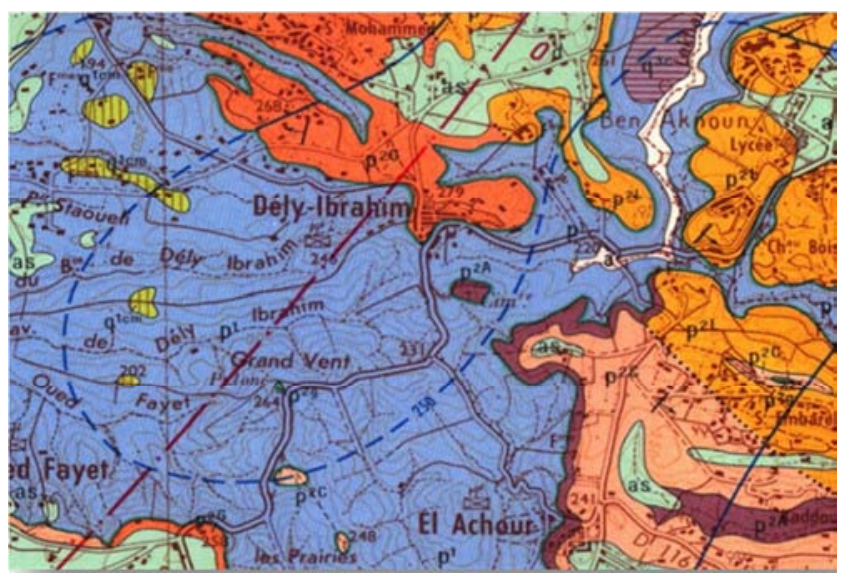

Figure 6. Geological formations from the card of Cheraga (at $1 / 50,000)$.

The results of the geotechnical characteristics obtained by the National Laboratory of Housing and Construction (NLHC 2011), Geotechnical studies of the slide area are indicated with the yellow color (figure 7). There are many results obtained by observations, insight investigations and in laboratory; the geotechnical characteristics are presented in table 1.

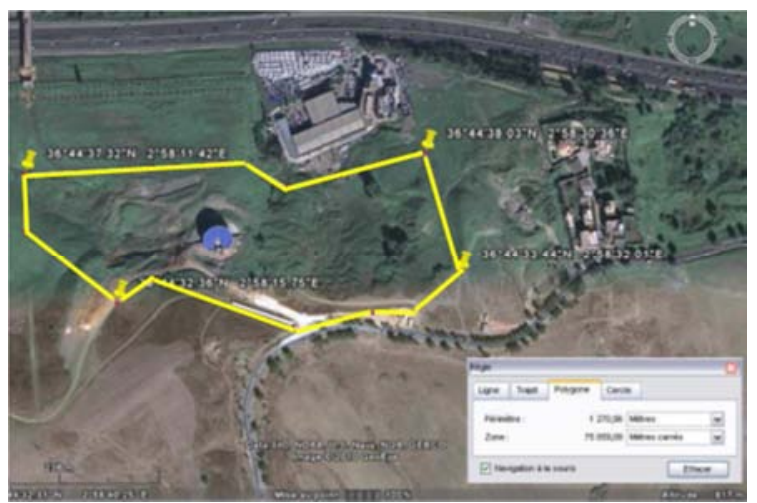

Figure 7. Limited area of geotechnical studies by the yellow color.

\subsection{State of the Area}

Numerous field of information in and around Dounia Park revealed the existence of landslides, showing that this zone is prone to land instabilities. As shown in figure 8 , there is a slope with a significant angle that makes slopes easy to be unstable in combination with other factors, such as water and earthquake. The trees (figure 8) confirmed the importance and the situation of our slope.

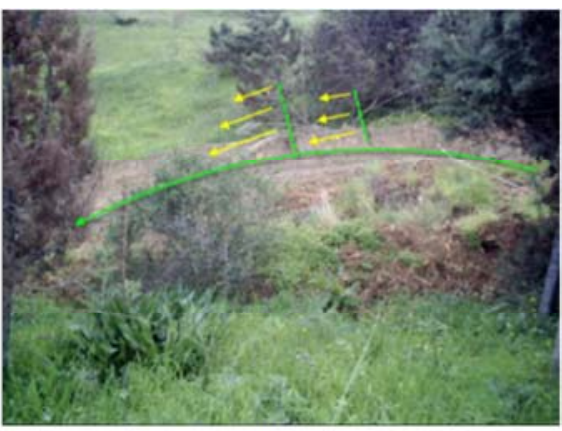

(b) (a)

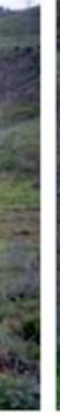

(b) The inclination of the trees.

The different results obtained by observations and insight investigations show the instability of the soils (figure 9), due to nature, behavior of soils and type of layers. The top layer of fill slides on the lower layer of marl, there no interaction between those soils, due to the behavior and thickness of fill and the preset of water of rainfall.
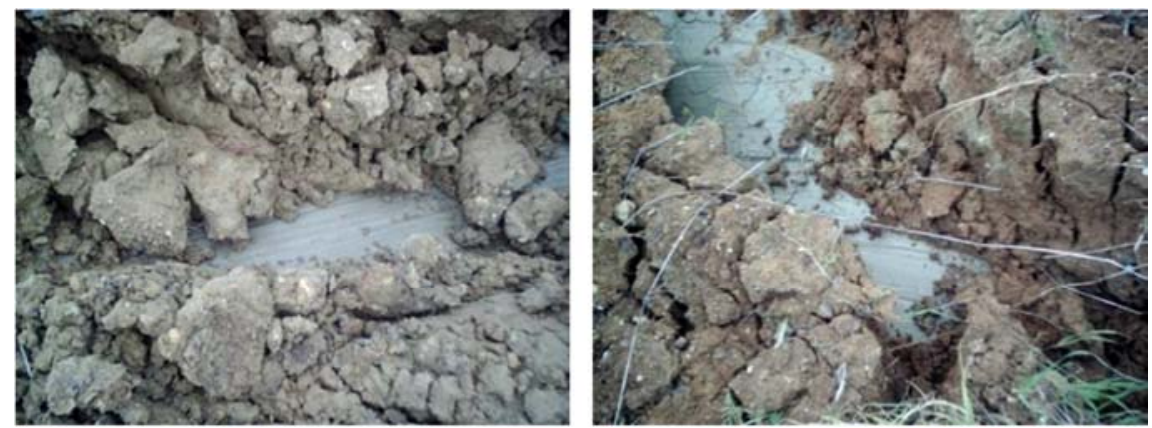

Figure 9. Examples on observations indicating the land instabilities.

During the site visit, different forms of instability were found, in which the scale varies from one place to another figure (10) shows various instabilities such as the first crack (figure 10 (a)), present in soil, this kind of cracks are everywhere. As mentioned previously, this is due to the characteristics of soil (fill, marl). Figure 10 (b) and 11 show many observations revealed that discontinuity orientation was important in the instability of soil and road as shown in figure 11, large longitudinal cracks next to the road are traced. That cracks can be explained by factors such as human 
causes (works in this area) and soil nature (marl and fill).

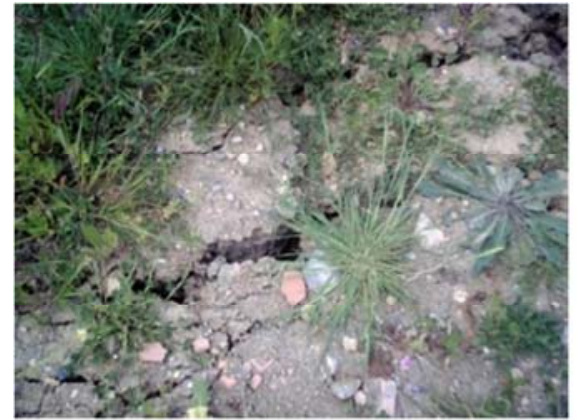

(a)

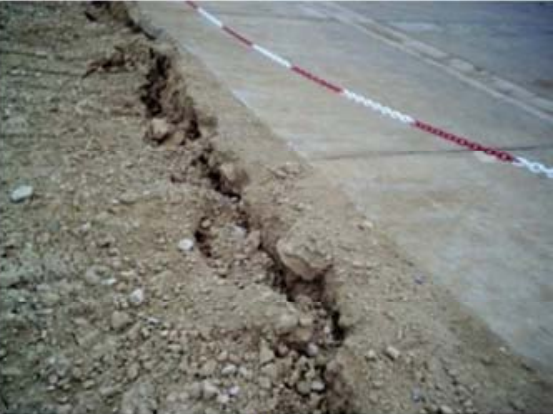

(b)

Figure 10. Fissures observed in the soil and near to the road N: 01 .

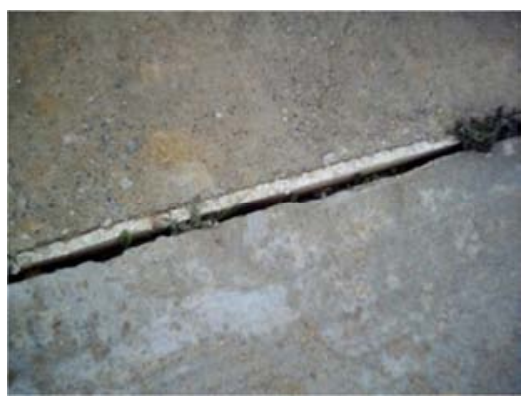

Figure 11. Fissure observed in and around the area of Dounia Park.
This study area is affected by two categorizes of landslides due to the morphological types of the landslides, and according to the classification of Cruden and al [19]: translational and rotational slides, as we see in figure 12 and 13 . The first is the translational slides, with highly variable masses, affected due to the marl and fill, and the angle of slope (figure 12 (a) and (b)). The second type of slides are rotational, they are shown in figures 13 (a) and (b). These landslides have different masses and rainfall plays the prominent role in this instability. The first type of slides (translational) are more gentle slopes compared to the second type (rotational) slope instability.

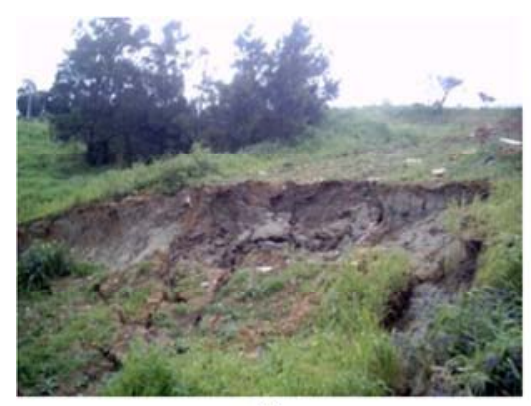

(a)

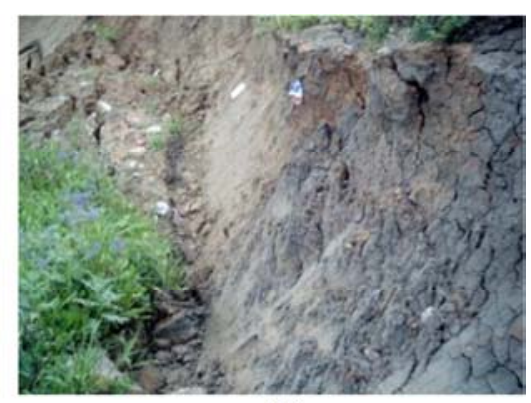

(b)

Figure 12. Observations indicating land instabilities, by the translational landslides.

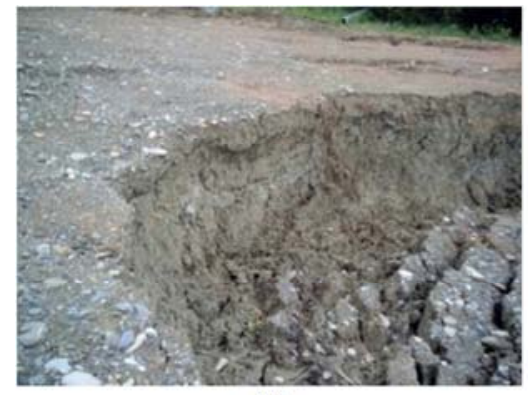

(a)

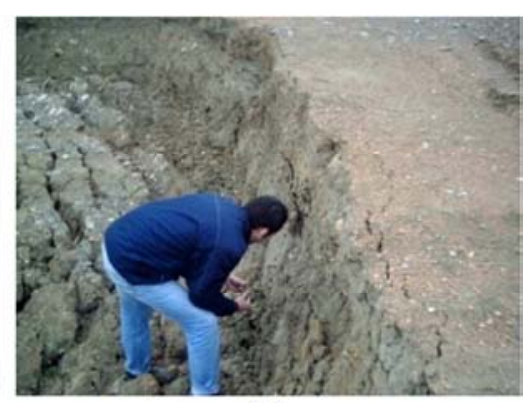

(b)

Figure 13. Two rotation landslides on the marl-filled layers.

\subsection{Geometry and the Properties of Soil}

To analyze the slope we need to define the characteristics of the material and the geometry of the slide; this is assisted with the shape of the area that is presented in a 3D format. Figures 14 (a) and (b) show the total vision of this area, and the most critical slope selected for analysis (figure 14 (b)), the length of this slope is $237 \mathrm{~m}$, and the height is $59 \mathrm{~m}$. There are three layers of soils, the landslide is simulate in a (2-D) two-dimensional with plane strain, the model of MohrCoulomb used to analyze this slope, all properties of soil are presented in Table 1. 


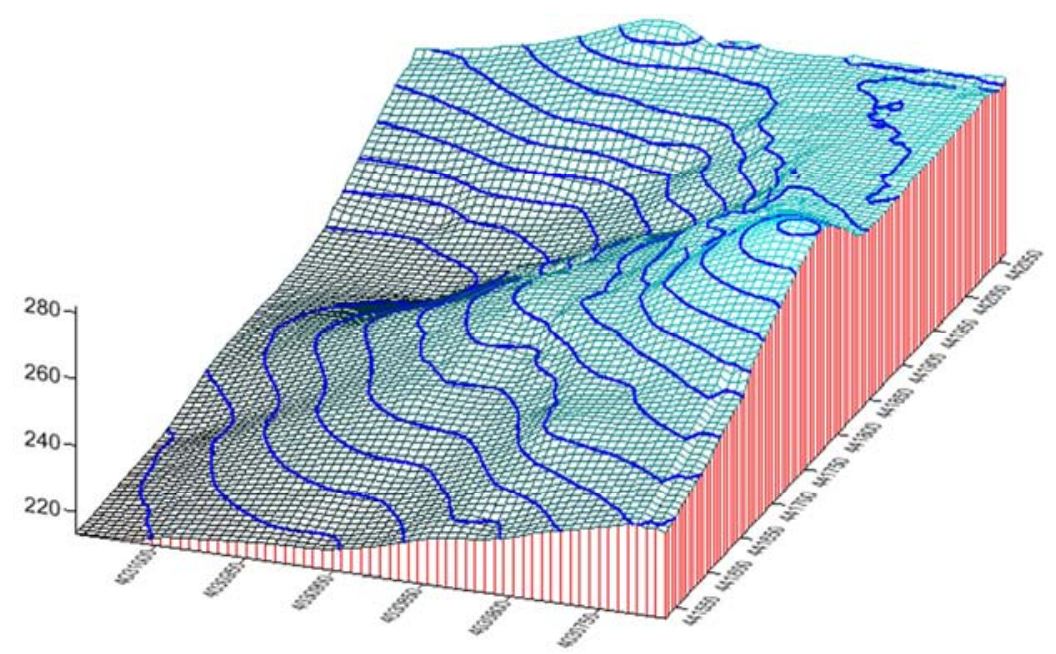

(a)

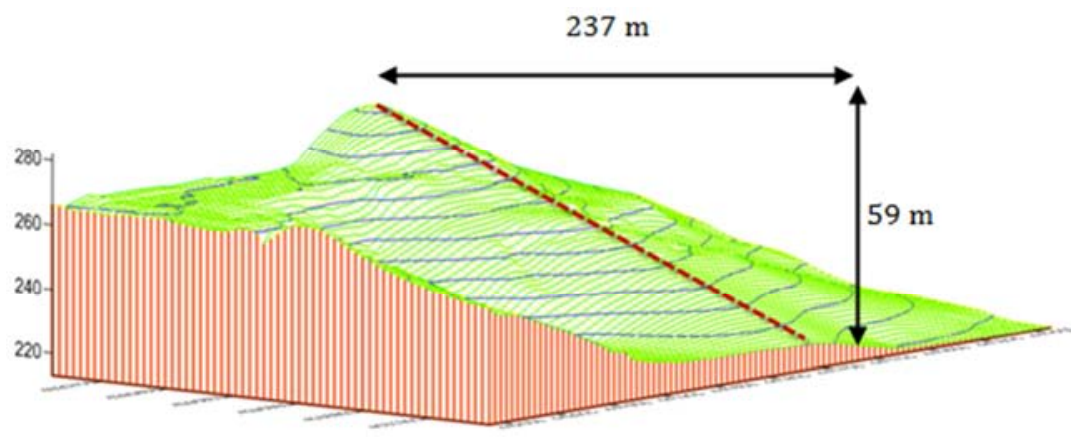

(b)

Figure 14. The view of the study area in $3 D$.

Table 1. The Properties of three layers.

\begin{tabular}{lllllll}
\hline Parameters & $\mathrm{E}\left(\mathbf{K N} / \mathbf{m}^{2}\right)$ & $\gamma_{\text {sat }}\left(\mathbf{K N} / \mathbf{m}^{\mathbf{3}}\right)$ & $\gamma_{\text {unsat }}\left(\mathbf{K N} / \mathbf{m}^{3}\right)$ & $\boldsymbol{\vartheta}$ & $\boldsymbol{\varphi}\left({ }^{\circ}\right)$ & $\boldsymbol{c}\left(\mathbf{K N} / \mathbf{m}^{2}\right)$ \\
\hline Layer (1) Fill & $20 * 10^{3}$ & 16.50 & 14.50 & 0.49 & 15 & 05 \\
Layer (2) Marl & $8.4^{*} 10^{4}$ & 22.40 & 19.60 & 0.30 & 10 & 27 \\
Layer (3) Marl & $3.5^{*} 10^{4}$ & 21.80 & 19.50 & 0.30 & 09 & 49 \\
\hline
\end{tabular}

\section{Numerical Modeling and Analysis Evaluation}

We used the finite element method to analyses this slope "Dounia Park", this method "FEM" is one of the great methods for analyzing structural mechanics and solid [20-23]. The developments of PC in last years, make the utilization of the numerical method to modeling geotechnical problems very popular. Many complex problems are addressed through this method; one of these problems is slope stability analysis. Recently, the finite element method has been used to evaluate a large number of embankments and slopes. Two simulation techniques used to modeling slope stability by the FEM: the most used is the SRM (Strength Reduction Method), in this technique the soil mass fails, by decreases gradually the cohesion $(c)$ and the tangent of the friction angle $(\tan \varphi)$ of the soil. The technique of SRM was used by Zienkiewicz et al. [24]. In addition, Smith and Griffiths [25], published the primary code used the Strength Reduction Method to analyze the slope stability. Numerous papers have used this technique (SRM) with FEM to study the slopes [26-35]. This method has been reviewed by Griffiths and Lane [33], Duncan [36], Taleb and Berga [37-38]. The factor of safety "SF" by the Mohr-Coulomb "M-C" it is the ration between the real and the critical strength parameters. The failure criterion of the M-C can be written as the equation for the line that signifies the failure envelope assumed by:

$$
\tau=\mathrm{c}+\sigma_{\mathrm{n}}+\tan \varphi
$$

Where; $\sigma_{n}$ : the normal stress; $\tau$ : the shear stress; $c$ : the cohesive strength, and $\varphi$ : is the internal friction angle. The factor of safety rendering to this equation:

$$
F S=\frac{c}{c_{r}}=\frac{\tan \varphi}{\tan \varphi_{r}}
$$

The Gravity Increase Method (GIM) it is the second procedure to modeling the slope stability, where the gravity 
forces such weight increases progressively until the failure of this slope. Tang [39], was implemented this method in a numerical code "Realistic Failure Process Analysis" (RFPA) and was used to study the construction of embankments by Colby et al. [40], and after by Li et al. [41]. The factor of safety by this technic (GIM) is the ratio between gravitational acceleration in the time of failure and actual gravitational acceleration is definite by the next equation:

$$
F S=\frac{g_{0}^{\text {trail }}}{g_{0}}
$$

$\mathrm{g}_{0}$ : Initial gravitational acceleration $\left(\mathrm{m} / \mathrm{s}^{2}\right)$; and, $\mathrm{g}_{0}^{\text {trail }}$ : Trial gravitational acceleration $\left(\mathrm{m} / \mathrm{s}^{2}\right)$.

Our modeling (figure 15) is founded on a shear strength reduction method (SRM) attached with the FEM, due to this method we can determine the factors of safety and failure mechanisms. We used the Mohr-Coulomb model to modeling this slope "Dounia Park.

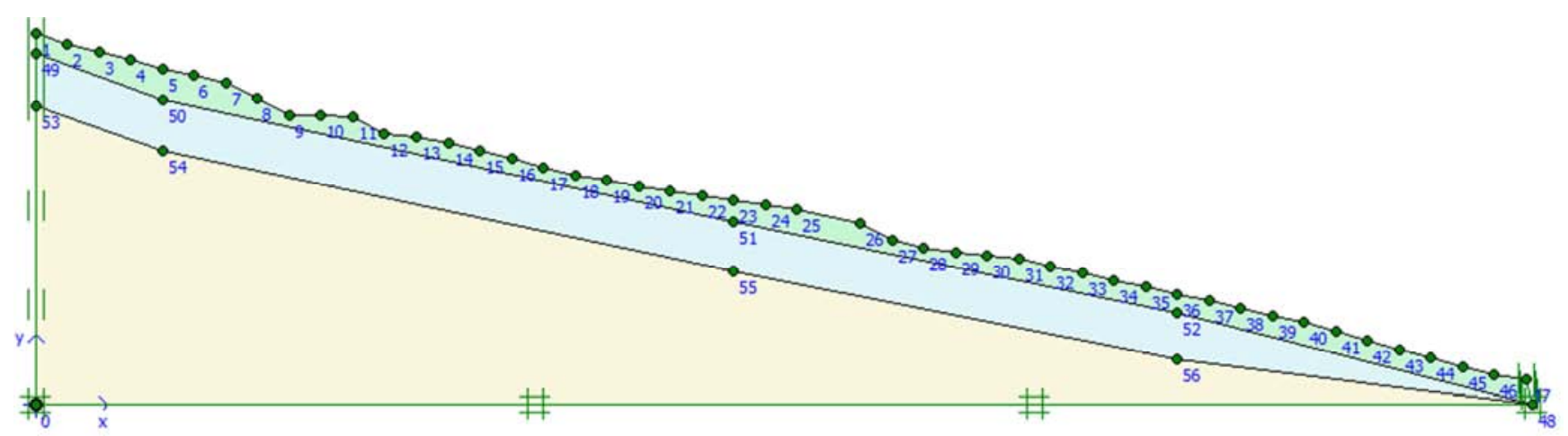

Figure 15. The slope geometry of Dounia Park in 2D.

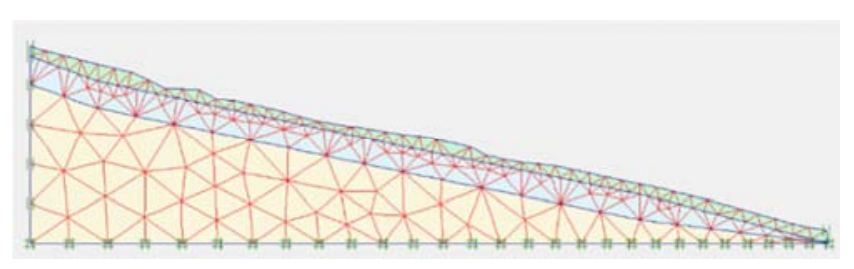

Figure 16. Meshed geometry by triangular elements.

The mesh selected for this modeling is constituted by triangular elements at 15 nodes (our profile contains 379 elements, and 3195 nodes) figure 16.

The slope stability of Dounia Park is assessed under conditions of characteristics soils and the slope angle by the strength reduction method SRM attached with the FEM. This area is affected by many landslides as shown previously. Figure 17, shows the failure surface of the slope. The factor of safety in this slope is $\mathrm{FS}=1.022$, we noticed the slope of Dounia Park is unstable in the top, the shape of this slide is a typical rotational landslide (figure 17).

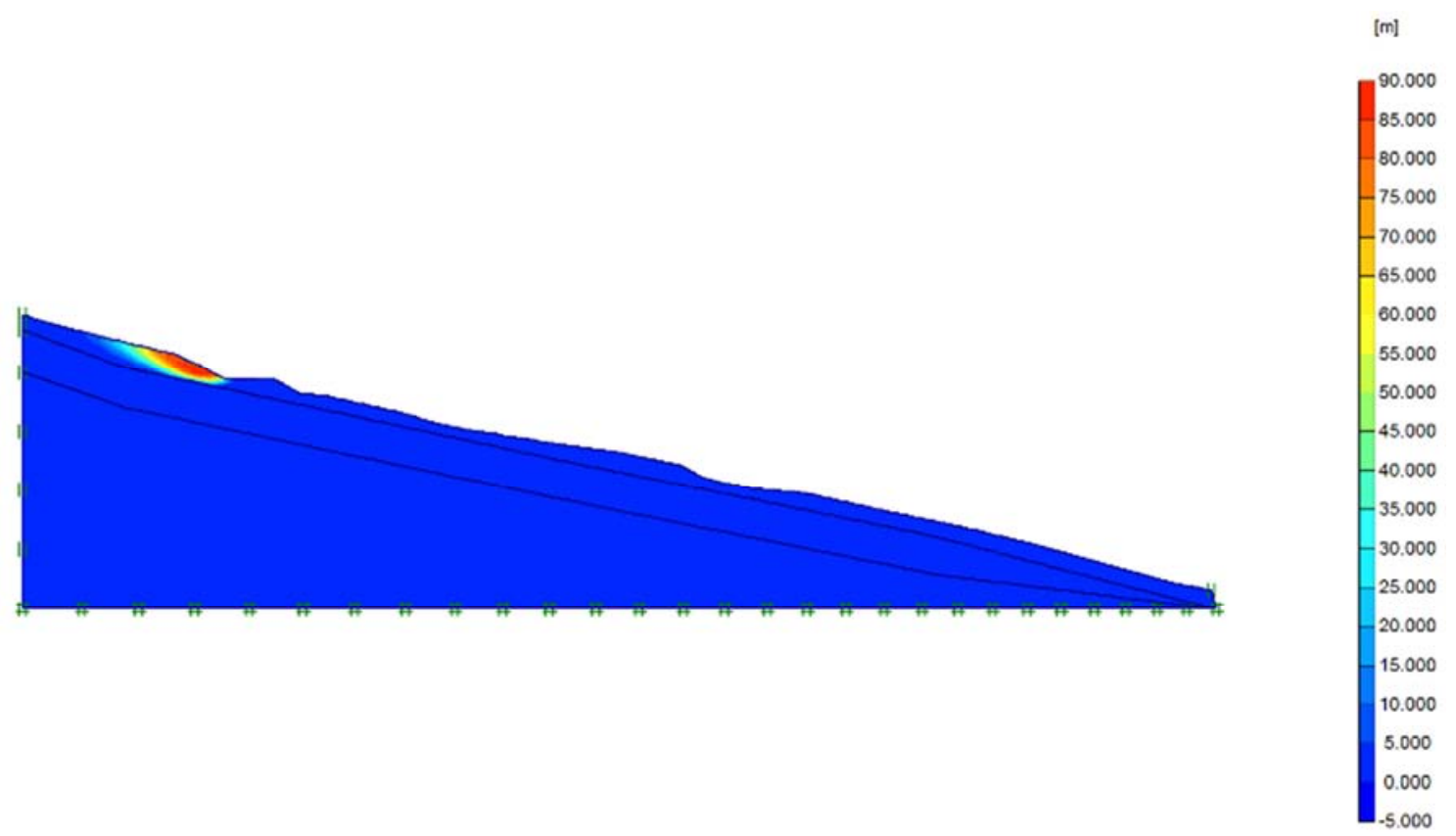

Figure 17. The critical slip surface. 
In figure 18 , the deformation mesh is presented, we note that the sliding surface take length of $41 \mathrm{~m}$ (figure 19). In addition, the sliding surface is just in the upper layer of the soil (fill), see figure 19. As we observed previously in the area of Dounia Park during the site visit that confirms that types of soil play an important role in this slope.

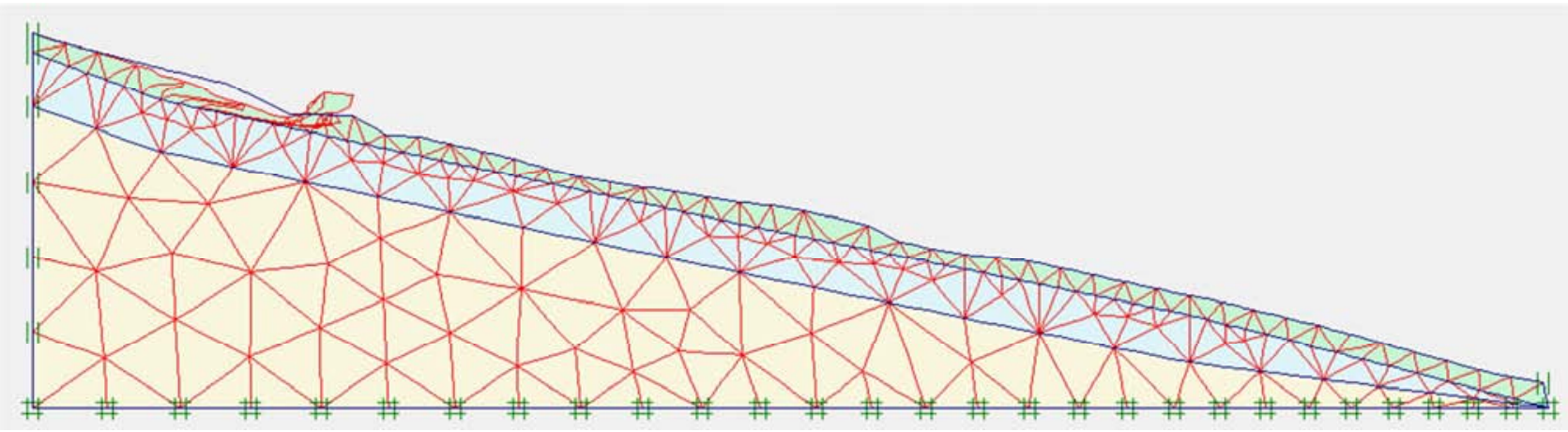

Figure 18. The failure surface by the mesh deformation.

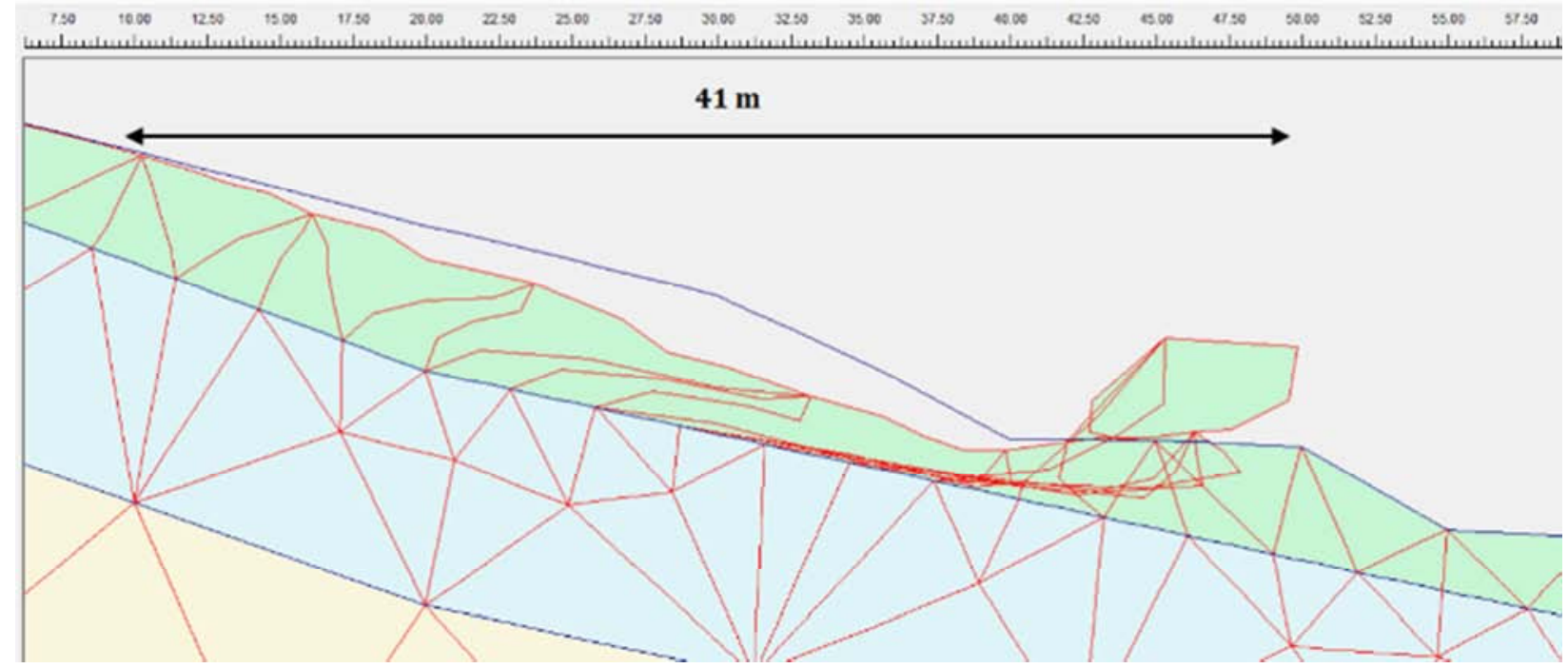

Figure 19. Zoom in the area of by mesh deformation.

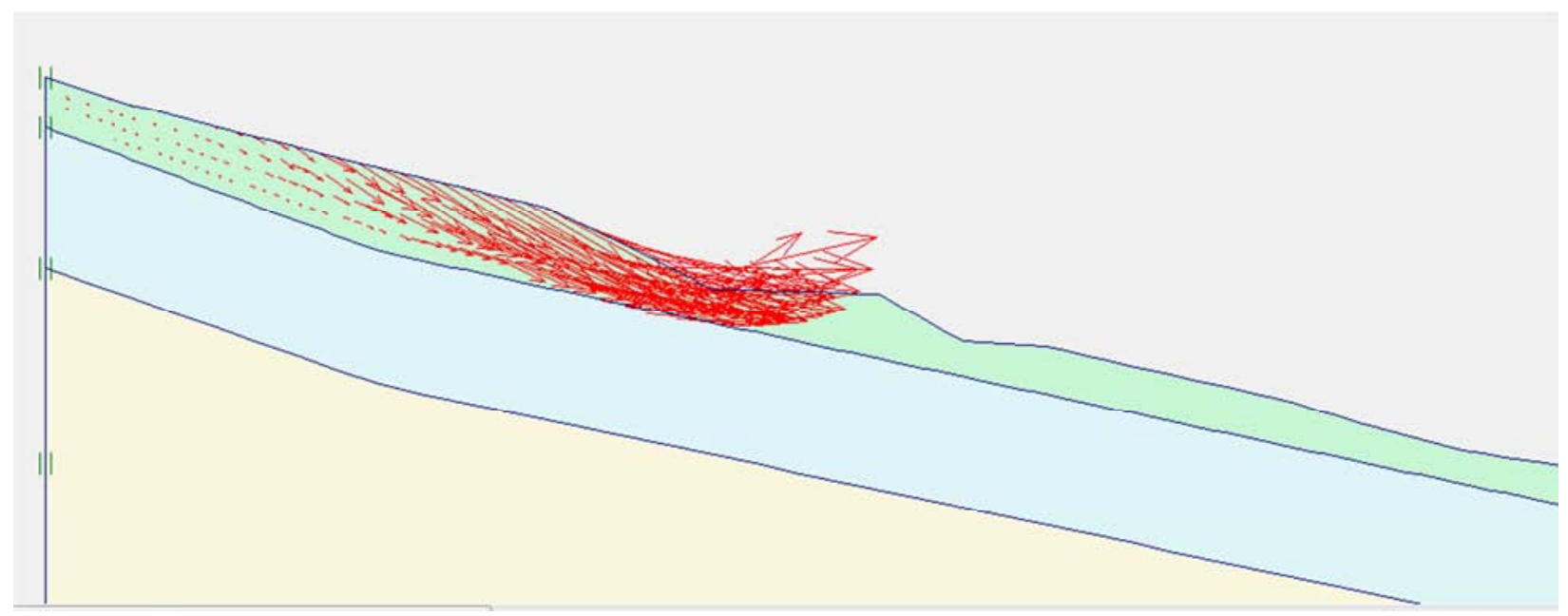

Figure 20. The failure surface by the displacement increments.

Figure 20 presents the displacement field of the slope analyzed by the equivalent $\mathrm{M}-\mathrm{C}$ criterion. In this figure, it is clear that fill layer slides to the marl. This confirms and shows the power of the SRM (strength reduction method) coupled with the FEM. 


\section{Conclusions}

Dounia Park is studied in this paper as a case of landslide stability. The results obtained in this article show numerous points. During the site visit, it was observed that the area of Dounia Park is affected by many types of instabilities (cracks, translation, rotation landslide) due to the characteristics of soil and the morphology characteristics of the slope. The results of numerical modeling of the Park by the strength reduction method coupled with the finite element method have also highlighted the situation of this slope. The results show that the slope is unstable, the shape of this slide is rotational, and the sliding surface is just in the upper layer of the slope (fill). The results (shape) of the numerical modeling analysis are identical to those obtained from the field observations, insight investigations, which confirmed the power of the finite elements method.

\section{Acknowledgements}

The authors are sincerely thankful to all members of National Laboratory of Housing and Construction (LNHC), because they gave us the geotechnical and geological characteristics of this slide area (Dounia Park).

\section{References}

[1] D. Machane, Y. Bouhadad, G. Cheikhlounis, J. L. Chatelain, E. H. Oubaichen, K. Abbes, B. Guillier, R. Bensalem Examples of geomorphologic and geological hazards in Algeria. Nat Hazardsn, (2008); 45: 295-308.

[2] Y Bouhadad, A Benhammouche, H Bourenane, A Ait Ouali, M Chikh, N Guessoum, The Laalam (Algeria) damaging landslide triggered by a moderate earthquake $(\mathrm{Mw}=5.2)$. Nat Hazards, (2010); 54: 261-272.

[3] L. Djerbal, B. Melbouci, Le glissement de terrain d'Ain El Hammam (Algérie): causes et évolution - Bulletin of Engineering Geology and the Environment, (2012); vol 71, pp 587-597.

[4] H. Riheb, B. Abderrahmane, L Yacine, B Mustapha, C. c. Abd El Madjid, D. Abdeslem, (2012) Geologic, topographic and climatic controls in landslide hazard assessment using GIS modeling: a case study of Souk Ahras region, NE Algeria. Quat Int 302 (2013): 224-237.

[5] M. S. Guettouche, Modeling and risk assessment of landslides using fuzzy logic. Application on the slopes of the Algerian Tell (Algeria). Arabian Geosci, (2012); 39: 1866-751. doi: 10.1007/s12517-012-0607-5.

[6] Y. Bouhadad, Occurrence and impact of characteristic earthquakes in northern Algeria. $J$ Nat hazards, (2013); 67: 1573-0840. doi: 10. 1007/s11069-013-0704-0.

[7] H. Bourenane, Y. Bouhadad, M. Said, G, Massinissa Braham. GIS-based landslide susceptibility zonation using bivariate statistical and expert approaches in the city of Constantine (Northeast Algeria). Bull Eng Geol Environ. (2014).

[8] E. E. Brabb, B. L. Harrod, (Eds) Landslides: Extent and Economic Significance, In Proceedings, 28th International Geological Congress: Symposium on Landslides, Washington, DC; (1989).
[9] R. L. Schuster, Socioeconomic significance of landslides. Landslides - Investigation and Mitigation, Special Report 247, A. K. Turner \& RL. Schuster (Eds.) Transportation Research Board, Washington DC, (1996), pp. 12-35.

[10] C. R. Sidle, H. Ochiai. Landslides. Processes, prediction, and land use. $A G U$ Books, Washington, DC, (2006).

[11] D. K. Keefer, Landslides caused by earthquakes: geological society of America bulletin, (1984); v. 95: 406-421.

[12] J. Vogt, Mouvements de terrain associés aux séismes en Afrique du Nord. Méditerranée, (1984); No 1-2, 43-48.

[13] A. Ayadi, F. Ousadou-Ayadi, S. Bourouis, H. Benhallou, Seismotectonics and seismic quietness of the Oranie region (western Algeria): the Mascara earthquake of August 18 1994, $\mathrm{Mw}=5.7, \mathrm{Ms}=6.0$. J Seismol 6: 13-23. (2002).

[14] Y. Bouhadad, A. Nour, N. Laouami, D. Belhai, The Beni-Ourtilane-Tachouaft fault and seismotectonic aspects of the Babors region (NE of Algeria). J Seismol 7: 79-88. (2003).

[15] D. Machane, Y. Bouhadad, E. H. Oubaiche, M. Hellel, F. Amrouche, K. Abbes, M. Messaoudi, G. Cheikh-Lounis, Description morphologique des effets induits par le séisme de Boumerdes (Algérie) du 21 mai $2003(\mathrm{Mw}=6.8)$. Mém Serv Géol Alg 12: 133-146, (2004).

[16] L. Djerbal, B. Melbouci, Numerical Modeling of the Climate Effect on the Evolution of the Landslide of Ain El Hammam (Algeria). Engineering Geology for Society and Territory Volume 2, (2015).

[17] R. Bahar, O. Sadaoui, and S. Sadaoui, Landslides Induced by Intense Rainfall and Human Interventions - Case Studies in Algeria. Engineering Geology for Society and Territory Volume 6, (2015).

[18] R. Bougdal, Urbanisation et mouvements de versants dans le contexte géologique et géotechnique des bassins néogènes d'Algérie du Nord, thèse de doctorat, Spécialité: Géologie appliquée, (2007).

[19] D. M. Cruden, D. J. Varnes, Landslide type and processes. In: Turner, A. K., Schuster, R. L. (Eds.), Landslides. Investigation and Mitigation. Special Report 247. Transportation Research Board. National Academy Press, Washington, (1996); pp. 3675.

[20] O. C. Zienkiewicz, R. L, Taylor. 4th edition, The Finite Element Method, vol. 2, McGraw-Hill, London, (1991).

[21] M. A. Crisfield, Non-linear Finite Element Analysis of Solids and Structures, John Wiley, Chichester, (1991).

[22] E. Hinton, D. R. J, Owen, Finite Elements in Plasticity: Theory and Practice, Pineridge Press, Swansea, Wales, (1980).

[23] K. J. Bathe, Finite Element Procedures, Prentice-Hall, New Jersey, (1996).

[24] O. C. Zienkiewicz, C. Humpheson, R. W. Lewis, Associated and nonassociated viscoplasticity and plasticity in soil mechanics. Géotechnique (1975); 25 (4): 671-89.

[25] Smith IM, Griffiths DV. Programming the finite element method. 2nd ed. John Wiley \& Sons, (1982).

[26] Naylor DJ. Finite elements and slope stability. Proceedings of the NATO Advanced Study Institute, Lisbon, Portugal, 1981. Numer. Methods Geomech. (1982): 229-44. 
[27] Donald IB, Giam SK. Application of the nodal displacement method to slope stability analysis. In: Proceedings of the 5th Australia-New Zealand conference on geomechanics, Sydney, Australia, (1988). p. 456-60.

[28] Ugai K. A method of calculation of total factor of safety of slopes by elastoplastic FEM. Soils Foundations (1989) 29 (2): 190-5.

[29] Matsui T, San KC. Finite element slope stability analysis by shear strength reduction technique. Soils Found (1992), 32 (1): 59-70.

[30] Ugai K, Leshchinsky D. Three-dimensional limit equilibrium and finite element analysis: a comparison of results. Soils Found (1995), 35 (4): 1-7.

[31] Song E. Finite element analysis of safety factor for soil structures. Chinese J Geotech Eng (1997), 19 (2): 1-7.

[32] Dawson EM, Roth WH, Drescher A. Slope stability analysis by strength reduction. Géotechnique, (1999), 49 (6): 835-40.

[33] Griffiths DV, Lane PA. Slope stability analysis by finite elements. Géotechnique, (1999); 49, (3): 387-403.

[34] Hammah RE, Yacoub TE, Corkum B, Curran JH. A Comparison of finite element slope stability analysis with conventional limit-equilibrium investigation. In: Proceedings of the 58th Canadian geotechnical and 6th joint IAH-CNC and CGS groundwater specialty conferences saskatoon, Saskatchewan, Canada, September, (2005).
[35] Zheng YR, Zhao SY, Kong WX, Deng CJ. Geotechnical engineering limit analysis using finite element method. Rock Soil Mech (2005), 26 (1): 163-8.

[36] Duncan J. M. State of the art: limit equilibrium and finite element analysis of slopes. J Geotech Eng, (1996), 122 (7): 577-96.

[37] T. H. Abderrahmane, B. Abdelmadjid, Etude Paramétrique du Couplage $(C, \varphi)$ et son Influence sur le Facteur de Sécurité au Glissement par la Méthode d'équilibre Limite. 1st International Seminar on Civil Engineering, University of Bechar (2013).

[38] T. H. Abderrahmane, B. Abdelmadjid, Evaluation d'un glissement avec comparaison entre MEL et MEF sous l'étude paramétrique du couplage "C- $\varphi$ "et leurs effets sur le facteur de sécurité et la surface de glissement. Colloque International « Caractérisation et Modélisation des Matériaux et Structures » CMMS14. Université Mouloud Mammeri de Tizi-Ouzou, (2014).

[39] C. A, Tang, Numerical simulation on progressive failure leading to collapse and associated seismicity. Int $J$ Rock Mech Min Sci, (1997) 34 (2): 249-61.

[40] C. Colby, Swan and YK Seo. Slope stability analysis using finite element techniques. 13 th Iowa ASCE Geotechnique Conference, USA, (1999).

[41] L. C. Li, C. A. Tang, W. C. Zhu, Z. Z. Liang, Numerical analysis of slope stability based on the gravity increase method, journal of Computers and Geotechnics, (2009). 